\title{
New professionals on tap? The human resource challenges in developing a new generation of municipal and local government managers in Nova Scotia
}

\section{Commonwealth Journal of Local Governance \\ Special Issue March 2010: \\ Commonwealth Local Government Conference \\ Freeport, Bahamas, May 2009 \\ http://epress.lib.uts.edu.au/ojs/index.php/cjlg}

\begin{abstract}
Andrew Molloy
David Johnson

Department of Political Science, Cape Breton University, Nova Scotia, Canada.
\end{abstract}
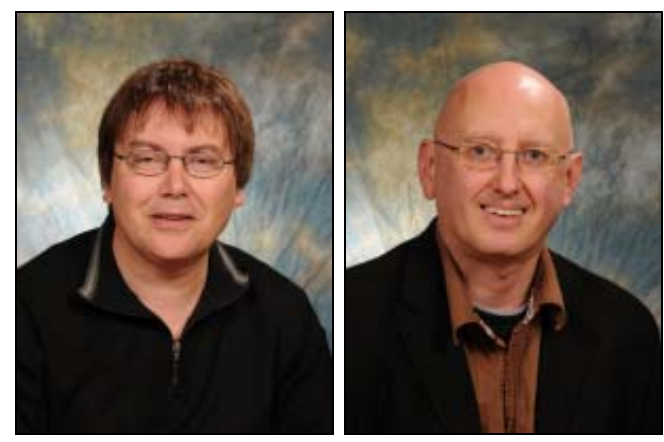

\begin{abstract}
Canadian governments are facing significant human resource management challenges due to pending retirements, projected labour market shortages and the workplace expectations of New Professionals. This paper explores human resource recruitment planning initiatives which have been undertaken by Nova Scotia municipalities in order to attract and retain a new generation of municipal government managers. We will argue, in line with a recent Association of Municipal Administrators of Nova Scotia municipal report, that Nova Scotia municipalities must take intergenerational issues into account for management succession planning to be successful. Our exploration of municipal succession planning will take place in the context of a larger study that we have completed on "New Professional" recruitment, retention and development initiatives in Canada.
\end{abstract}

Keywords: New professionals, Intergenerational change, Human resource management, Nova Scotia, Municipalities. 


\section{Introduction}

Demographic trends are causing more municipalities to take a serious look at workforce planning, and in particular, recruiting young talent. These trends are continually discussed by public sector leaders, managers, and employees and are well known. Despite the urgency for change and the recognition that "something needs to be done," few public sector organizations have executed strategies that are forward-thinking and anticipate future staffing and management challenges.(Association of Municipal Administrators of Nova Scotia, 2006:5).

Many of the major industrial societies in the world are confronting a growing demographic problem. Their populations are aging; their population longevity, in most instances, is increasing; their baby boom generations are preparing to retire and leave active employment; and the population cohorts coming behind the boomer generations are substantially smaller than those they are replacing; meaning that, in most instances, countries will witness an overall decline in their workforce during the early to middle decades of the $21^{\text {st }}$ century. These trends are presenting all organizations within the developed world with great challenges respecting intergenerational change, but also great opportunities. The challenges are those of how to cope with the pending retirement of the Baby Boom generation (or 'Boomers'), how to engage in succession planning and intergenerational transition, and how to recruit, train, and retain the new employees of Generation X and more importantly, Generation Y - the New Millennials (referred to here as 'the Millennials'). The opportunities are to reshape workplaces and reconfigure how workplaces actually work. With the exit of the baby boom generation and the entry of new, younger generations into the workplace and into positions of managerial importance, organizations are coming to a unique period of time where old patterns of institutional thought and behaviour can be superseded or transformed and new approaches to organizational life can be promoted.

The contemporary literature on human resource management is replete with studies on intergenerational change and the need for organizations to understand the complex and changing human resource environment they are confronting. And key to understanding such complexity is for organizational leaders to recognize the nature of the multigenerational workforces they already possess and the need to manage them more effectively. As Kaye, Scheef and Thielfoldt stress, human resource managers need to "engage the generations" present within their workforces, and they need to understand the core fundamental characteristics of these generations and the type of talent and 
world-view that each generation brings to the workplace and to its understanding of work (2003: 25).

This in turn leads to a strategic management focus on recruitment and what is being increasingly referred to as 'talent management'. Human resource managers have to become much more proactive in their staffing functions than reactive. Authors such as Gravett and Throckmorton (2007), Martin and Tulgan (2006), Brown and Williams (2003), Lancaster and Stillman (2002), and Zemke, Raines and Filipczak (2000) have produced extensive works on the challenges facing contemporary organizations as they cope with changing demographics, yet also the great opportunities they possess in coming into a time when they can witness a 'changing of the guard', allowing them to engage in critical and considered succession planning. Organizations can identify the best practices and traditions of their existing standard procedures that they wish to pass on to the new employees and new managers who will be entering their ranks from Generation $\mathrm{X}$ and the Millennials. At the same time, they can take the opportunity to supersede existing ways of doing things, to promote and establish better ways of thinking and acting with regard to organizational behaviour, and encourage new employees to bring new values to old organizations. By so doing, organizations can rejuvenate their institutional life. Thus intergenerational change should not simply mean a quantitative replacement of senior and retiring employees with younger and newer employees, but a qualitative change in the way organizations see themselves, how they think and act, how they relate to both their own employees and those they serve in the outside world, and how they engage with the broader world around themselves. Intergenerational change has the promise of being transformational for those organizations willing and able to embrace its challenges and opportunities.

Against this background, this paper will explore human resource initiatives undertaken by municipalities in Nova Scotia, Canada, in order to attract and retain a new generation of local government managers. We will argue, in line with a recent Association of Municipal Administrators (AMA) of Nova Scotia report, that Nova Scotia municipalities must take intergenerational issues into account for management succession planning to be successful. Our exploration of municipal succession planning will take place in the context of a larger study on "New Professional" recruitment, retention and development initiatives in Canada (Johnson and Molloy, 2010 [forthcoming]). 


\section{The Canadian context}

Tensions and concerns regarding demographic change and intergenerational transformations are being experienced across many developed and developing countries. There is growing concern in Canada with respect to these matters, with Canadian analysts highlighting many of the same types of prognostications and tensions found elsewhere. All sectors of the Canadian economy are projected to face labour market challenges, as baby boom retirements occur over the next few years (Policy Research Initiative, 2006). In 2001, the Baby Boomers constituted 47\% of the Canadian workforce (UNSM 2007 Spring Workshop:8). Looming labour market shortages will be a new phenomenon to a country where historically supply has outstripped demand.

In a 2006 report for the Urban Futures Institute, labour market researchers predicted that a 'perfect storm' will hit the Canadian economy over the coming decades. This 'perfect storm' will be the result of labour demand outstripping labour supply whereby in terms "of economic trends, employment is projected to reach 35.2 million in 2055 - from the perspective of demographic trends, the labour force is projected to reach 22.8 million by the same year" (Ramlo and Berlin, 2006:25). Shorter term labour market projections by the Urban Futures Institute are no less comforting. It has been estimated that "some 9.8 million Canadian baby boomers are approaching retirement. By 2020, the number of Canadians retiring each year will be 425,000" (CBC News, 2005: 2-3). The Canadian Labour Congress has noted that these projected labour market trends will produce skill shortages in a number of areas, including public administration (Association of Municipal Administrators of Nova Scotia, 2006:9).

Federal and provincial governments have responded to workforce aging with public sector renewal initiatives to re-brand themselves as employers of choice. As part of these initiatives, 'New Professionals' human resource policies and programs have been developed on the basis of intergenerational change studies as well as workplace experience with the new generations of public service employees. Public sector renewal performance targets are being implemented to measure the effects of such policies and programs.

Municipal and local governments across Canada are also going through a process of public sector renewal. And as in the case of the senior governments, municipal public sector renewal involves developing intergenerational-based human resource management 
recruitment programs. By developing such programs, through the assistance of provincial municipal and local government planning bodies, municipalities are attempting to meet projected medium term labour market shortages.

\section{New professionals and new professionalism}

As noted above, a number of provincial governments and larger municipalities as well as the federal government have developed New Professionals policies and programs in order to attract and retain young Canadians. These policies have in turn given birth to what its advocates stress as a new way of looking at public sector management, namely 'New professionalism'. Much of the theory and practice behind New Professionalism has been influenced by the theory of New Public Management (NPM). At the outset, the thrust of NPM was enhancing the power and role of elected politicians in policy-making. During the 1990s, however, through the work of such authors as Aucoin (1995), Osborne and Gaebler (1993), Purchase and Hirshorn (1994), Borins (1995), and Kernaghan, Marson and Borins (2000), the focus of the NPM movement in Canada shifted to public sector organizations becoming more capable, responsive and innovative. In this sense, "public management looks at public organizations qua organizations and seeks to understand or improve features of organizational life such as leadership, strategic management, organizational climate, service quality, innovation, the measurement of outputs, performance and 'client satisfaction' and so on” (Report of the Task Force on Public Service Values and Ethics, 1996:29).

While there is debate in the academic literature respecting the theoretical and practical merits of NPM (Thomas, 1993; Trebilcock, 1994; Savoie, 1995; Borins, 1995), the impact of such thinking on how governments see themselves and the contemporary public sector reform process cannot be denied. In Canada, Kernaghan, Marson and Borins (2000) have documented the interest shown by all levels of government in the development of the new public organization: one that will transcend traditional bureaucracies' narrow focus on position, rules, process, and centralized command and control power, for a post-bureaucratic organization that will be devoted to citizen service, leadership, collaboration, change-and results-orientation, decentralization, and social responsiveness (2000, 4-14).

Similarly, New Professionalism is about public service organizations being more open to change, more welcoming to new public servants, and more responsive to their interests, 
needs, and skills. As post-bureaucratic New Professional organizations, public service institutions are to be more decentralized, less hierarchical, less fixated on organizational imperatives and interests, and more concerned with the concepts of service delivery, results-orientation, and people-centredness. New Professional organizations also enable all staff to undertake their work with the latest of information and communications technologies while respecting and promoting the concept of work-life balance. Rather than being dominated by rule-bound, process-oriented, command and control cultures, the new public service is to be characterized by innovative practices and effective outcomes derived from a working environment marked by management and employee empowerment, risk-taking, greater openness, collaboration, and progressive leadership (New Professionals, 2001; Institute of Public Administration of Canada, 2003; Kernaghan, Marson, Borins, 2000). New Professionalism champions the public service as a career place of choice for young Canadians wishing to have a career that offers them the best of professional training and development while also giving them a job that matters to Canada and Canadians.

New Professionals have been defined by the Institute of Public Administration of Canada (IPAC) as those new public servants who have been employed in government for a period of eight years or less. They are viewed by governments, public service commissions and young people themselves as upwardly mobile entrants who embody the changes taking place within Canadian public services. This group of new public servants has sought to establish an identity for themselves, searching to declare their vision and purpose of public service, and striving for careers in public administration with advancement into the professional and managerial ranks of government.

New Professionals clearly embrace and actively seek motivational forms of empowerment, which make up a large part of their core value system. New Professionals want to become fully involved. They seek out as many training and development opportunities as possible in order to become better equipped to do their jobs. They are also strongly supportive of individualized learning plans as an important career progression tool. According to Canadian federal public service data, "30 of 36 Deputy Ministers have indicated that at least $90 \%$ of their employees will have learning plans in place by March 2008” (Canada Public Service Agency, 2007-08:1). Visible signs of recognition for what New Professionals do are also greatly appreciated. The public service has increasingly paid attention to formal means of recognition and reward 
through various measures, including the encouragement and acceptance of employee suggestions, awarding bonuses for especially significant contributions, acknowledgement in newsletters of employees’ achievements, and awards programs.

Balancing home and work life and having 'flex time' opportunities are valued by some New Professionals, who will seek out those departments and agencies who are willing to use work-life balance as a motivational and empowerment tool to build a well performing organization. However, others accept the traditional public service reality of having to work long hours as a matter of course, and may see it as a means to establish their credentials - even if that means becoming an 'adrenaline junkie' for a period of time in the process (New Professional Focus Groups, May, 2006).

Increasingly, federal, provincial and local governments are looking toward the New Professionals as a vital source of 'new blood' in their quest for institutional renewal and rejuvenation. New Professionals are perceived as "future leaders who are eager to progress into leadership roles, they want to add value to your organization and they want to make a difference in their community through public service" (Sherwood and Matthews, 2003:1). These Generation X and Generation Y public servants have different attitudes, expectations and working styles than those of previous generations. Public service managers must become attuned to the professional ambitions and requirements of their new and future employees as an important aspect of intergenerational change. They must prepare their junior managers for executive succession, staff their organizations with new talent, train and develop new employees, and redesign their human resource systems and workplace institutions so that they can and will meet the needs of their public services.

Correspondingly, New Professionals policies have been developed as a form of market branding in order to underline an employer commitment to effective talent management. (Centre for Leadership and Learning, 2006). One example of this can be found in the Ontario Public Service (OPS), which has created a Youth and New Professionals Secretariat (YNPS) as part of the Centre for Leadership and Learning. According to promotional material from the Ministry of Government Services, the YNPS was created "to provide an enterprise-wide approach for attracting, recruiting, developing and retaining youth and new professionals to the OPS” (Youth and New Professionals, 2006: 
4). As such the YNPS is billed as one of the "supporting strategies beneath both the OPS HR plan and the OPS Framework for Action” (Youth and New Professionals, 2006:4).

In attempting to meet the labour market challenges associated with projected retirements, population diversity, skill shortages in key capacity areas, and keeping pace with modern management practices, the OPS developed a service-wide human resources plan in 2005 (Youth and New Professionals, 2006: 3). As a key component of this plan, the YNPS "will lead a government-wide approach to strategically branding and marketing the OPS as an employer of first choice” (Youth and New Professionals, 2006:7).

In similar vein, the provincial governments of Manitoba and Saskatchewan have created New Professionals networks. These are designed to promote capacity building whereby New Professionals will develop events and activities for themselves through planning teams and committees. In Manitoba, the New Professionals network flowed from a first New Professionals Day held in October 2005 (Manitoba Civil Service Commission, 2008:1). It is sustained through the work of New Professional volunteer groups. The New Professionals network in Saskatchewan began with a roundtable discussion 'Make the Most of your Public Service Career' (Public Service Commission, 2008: 1). It is run by a New Professional advisory board.

\section{The case of Nova Scotia}

There are currently 55 municipal governments in Nova Scotia. The two largest of these are the Halifax Regional Municipality (HRM) and the Cape Breton Regional Municipality (CBRM). While some of the larger municipalities possess dedicated human resource functions, many do not (Association of Municipal Administrators of Nova Scotia, 2006:9). The use of provincial and national bodies and associations therefore becomes important when longer term human resource planning is required. One of the provincial bodies is the Union of Nova Scotia Municipalities (UNSM). This is a not-forprofit organization mandated to represent the provincial interests of municipal governments across Nova Scotia (Union of Nova Scotia Municipalities, 2009:1). One of UNSM's current priorities is to develop human resource initiatives to help attract a new generation of municipal public service managers. These initiatives are being designed to reflect the values, attitudes and expectations of incoming generations, and in so doing, it is hoped that municipal recruitment programs and services will be successful in filling current and future management vacancies. 
Nova Scotia municipalities are reportedly having "difficulty in attracting qualified candidates in certain areas” (Association of Municipal Administrators of Nova Scotia, 2006:9). In this respect they face demographic challenges similar to other public administration organizations across the country. Nova Scotia in fact appears to be a bit further along the curve. The following table illustrates the impact of retirements, lower birth rates, higher qualification levels and time spent on post-secondary education on the national and Nova Scotia labour forces.

Figure 1: Impacts on the Labour Force

\begin{tabular}{|l|l|l|}
\hline Impacts on Labour Force & Canada & NS \\
\hline Workforce is aging & $\begin{array}{l}\text { Increase from 11\% to 20\% of } \\
\text { workers within 10 years of } \\
\text { average retirement age (between } \\
1987 \text { to 2002) } \\
\begin{array}{l}\text { Average age of the workforce } \\
\text { increased from 37 to 39 years } \\
\text { (between 1991 to 2001) }\end{array}\end{array}$ & $\begin{array}{l}\text { Increase from 10\% to 22\% of } \\
\text { workers within 10 years of } \\
\text { average retirement age (between } \\
1987 \text { to 2002) } \\
\text { Average age of the workforce } \\
\text { increased from 37 to 39 years } \\
\text { (between 1991 to 2001) }\end{array}$ \\
\hline People are retiring earlier & $\begin{array}{l}\text { Average retirement age dropped } \\
\text { from 64 to 61 (between 1987 to } \\
2002)\end{array}$ & $\begin{array}{l}\text { Average retirement age dropped } \\
\text { from 64 to 60 (between 1987 to } \\
2002)\end{array}$ \\
\hline People are having few children & $\begin{array}{l}18 \% \text { decrease (between } \\
1991 / 1992 \text { to 2003/2004) }\end{array}$ & $\begin{array}{l}29 \% \text { decrease (between } \\
1991 / 1992 \text { to 2003/2004) }\end{array}$ \\
\hline $\begin{array}{l}\text { Young people stay in school } \\
\text { longer }\end{array}$ & $\begin{array}{l}62 \% \text { of workers have post } \\
\text { secondary education (2005) }\end{array}$ & $\begin{array}{l}63 \% \text { of workers have post } \\
\text { secondary education (2005) }\end{array}$ \\
\hline $\begin{array}{l}\text { Jobs are requiring higher skill } \\
\text { levels (Association of Municipal } \\
\text { Administrators of Nova Scotia, } \\
\text { 2006:4). }\end{array}$ & $\begin{array}{l}33 \% \text { increase in number of } \\
\text { people in jobs that usually require } \\
\text { a university education (between } \\
1991-2001) \\
17 \% \text { increase in number of } \\
\text { people in manager roles } \\
\text { (between 1991-2001) }\end{array}$ & $\begin{array}{l}18 \% \text { increase in number of } \\
\text { people in jobs that usually require } \\
\text { a university education (between } \\
1991-2001) \\
11 \% \text { increase in number of } \\
\text { people in manager roles } \\
\text { (between 1991-2001) }\end{array}$ \\
\hline
\end{tabular}

Source: Statistics Canada, Canada's Workforce: Paid Work;

Association of Municipal Administrators of Nova Scotia, 2006:7

Just as the federal and provincial governments of Canada are focusing on renewing their organizations through New Professional human resource planning initiatives, municipalities are following suit. In Nova Scotia, the Next Generation Project was created through a partnership comprising UNSM, the Association of Municipal Administrators (AMA) of Nova Scotia, and Service Nova Scotia and Municipal Relations (SNSMR). The purpose of the project was to educate municipalities on the need to develop recruitment strategies for attracting a new generation of managers. This 
flowed from concerns that there had not been significant discussion of the impact of the aging workforce on municipalities in Nova Scotia. Some municipal managers would argue that Nova Scotia municipalities are ten years behind what senior levels of government are doing when it comes to succession planning (Personal Communication, 3 April 2009). The lack of human resource staffing in smaller municipalities may play a role in hindering such medium to longer term planning.

In 2006 the Next Generation Project produced a consultant's report: 'Reality Check: Do You Know Where Your People Are? Attracting the Next Generation of Municipal Government Managers in Nova Scotia'. The report focused on raising the profile of the issue, as well as providing recommendations for recruiting new municipal managers (Association of Municipal Administrators of Nova Scotia, 2006). Its recommendations were made in the context of "recognizing the diversity in size and location of our municipalities” (UNSM 2007 Spring Workshop: 3). Primary data for the report was drawn from online surveys of both AMA members in general and in particular AMA members who had human resources responsibilities. Four focus groups of municipal employees and hiring managers were also conducted (Association of Municipal Administrators of Nova Scotia, 2006).

The report begins with an analysis of current workforce demographics in Nova Scotia, and subsequently identifies areas of critical need that municipalities need to consider (Association of Municipal Administrators of Nova Scotia, 2006:9). Amongst the occupational groups shown in Figure 2, the 'oldest' age structures include senior government managers and government managers in economic analysis, policy development and program administration. 55\% of senior government management and officials are 45 or older. A further $41 \%$ are in the $35-44$ cohort, whilst only $4 \%$ are aged 25-34. Moreover, as in the federal and provincial public services, the largest age cohort of the senior management 'feeder group' is $45-54$ years old, and in total $62 \%$ are 45 of older. $26 \%$ are in the $34-44$ cohort, with only $11 \%$ are in the $25-34$ age group.

Within municipalities, the average age of employees is 48, and "within the next 10 years in Nova Scotia, for every two people retiring, there will be less than 1 to take their place" (UNSM 2007 Spring Workshop: 5). This projected deficit in municipal employees can be explained by a falling retirement age, lower birth rates, increased participation in post- 
secondary education, and higher labour force qualification standards (Association of Municipal Administrators of Nova Scotia, 2006).

Figure 2: Age Distribution of Specific Occupations within Nova Scotia (Listed in ascending order based on percentage of workers under 35)

\begin{tabular}{|c|c|c|c|c|c|c|}
\hline \multirow{2}{*}{$\begin{array}{l}\text { Occupations } \\
\text { (North American Industry } \\
\text { Classification System) }\end{array}$} & \multicolumn{6}{|c|}{ Years of Age } \\
\hline & $15-24$ & $25-34$ & $35-44$ & $45-54$ & $55-64$ & $64+$ \\
\hline $\begin{array}{l}\text { Senior government managers and } \\
\text { officials (A012) }\end{array}$ & $0 \%$ & $4 \%$ & $41 \%$ & $45 \%$ & $10 \%$ & $0 \%$ \\
\hline $\begin{array}{l}\text { Government managers in economic } \\
\text { analysis, policy development, and } \\
\text { program administration (A332) }\end{array}$ & $0 \%$ & $11 \%$ & $26 \%$ & $56 \%$ & $7 \%$ & $0 \%$ \\
\hline $\begin{array}{l}\text { Public works maintenance } \\
\text { equipment operators (H612) }\end{array}$ & $4 \%$ & $15 \%$ & $34 \%$ & $31 \%$ & $16 \%$ & $0 \%$ \\
\hline Utilities managers (A392) & $0 \%$ & $27 \%$ & $25 \%$ & $30 \%$ & $18 \%$ & $0 \%$ \\
\hline Administrative clerks (B541) & $7 \%$ & $20 \%$ & $37 \%$ & $26 \%$ & $8 \%$ & $1 \%$ \\
\hline $\begin{array}{l}\text { Police officers - except } \\
\text { commissioned (G611) }\end{array}$ & $5 \%$ & $22 \%$ & $38 \%$ & $32 \%$ & $2 \%$ & $1 \%$ \\
\hline Civil engineers (C031) & $3 \%$ & $27 \%$ & $34 \%$ & $23 \%$ & $12 \%$ & $2 \%$ \\
\hline $\begin{array}{l}\text { Inspectors in public and } \\
\text { environmental health and } \\
\text { occupational health and safety } \\
\text { (C163) }\end{array}$ & $14 \%$ & $14 \%$ & $31 \%$ & $27 \%$ & $13 \%$ & $0 \%$ \\
\hline $\begin{array}{l}\text { Lawyers and Quebec notaries } \\
\text { (E012) }\end{array}$ & $1 \%$ & $28 \%$ & $26 \%$ & $30 \%$ & $15 \%$ & $1 \%$ \\
\hline $\begin{array}{l}\text { Heavy-duty equipment mechanics } \\
\text { (H412) }\end{array}$ & $8 \%$ & $22 \%$ & $32 \%$ & $28 \%$ & $9 \%$ & $1 \%$ \\
\hline $\begin{array}{l}\text { Economic development officers and } \\
\text { marketing researchers and } \\
\text { consultants (E033) }\end{array}$ & $11 \%$ & $32 \%$ & $34 \%$ & $16 \%$ & $7 \%$ & $1 \%$ \\
\hline $\begin{array}{l}\text { Computer and information systems } \\
\text { occupations (C070) }\end{array}$ & $14 \%$ & $39 \%$ & $29 \%$ & $14 \%$ & $3 \%$ & $0 \%$ \\
\hline
\end{tabular}

Source: Statistics Canada, 2001 Census Data (Association of Municipal Administrators of Nova Scotia, 2006:9). Note: percentages may not add up to $100 \%$ due to rounding

The workforce data thus highlights the need to create successful recruitment strategies in order to replace the Baby Boomer management with a new generation of municipal managers. The Reality Check report notes that "many towns have already 'hit the hump' with respect to retirements" (Association of Municipal Administrators of Nova Scotia, 2006:40). The demographic bulge that occurred with the Baby Boom enabled companies to cherry-pick from among millions of highly educated, ambitious workers, often at 
bargain rates. But organizations will be scrambling to replace retiring Boomers with a dramatically smaller cohort of ' $X$ 'ers. As a result, organizations will also have to dip into the Millennial pool of talent that will unfortunately still be 'wet behind the ears'. And never mind only reaching down the ladder; to compensate for lack of experience, companies will also have to find persuasive ways to reach up and encourage Boomers and even older workers to stick around or dive back into the job market (Lancaster and Stillman 2002:156). The provincial government is enabling senior workers to stay on through the elimination of mandatory retirement from July 2009. Some of the next generation of managers in Nova Scotia may come also from under-represented groups and immigrants. 'One size fits all' recruitment strategies will not work in attracting these different target groups (UNSM 2007 Spring Workshop: 15).

\section{Recruiting the new professionals: Challenges and opportunities}

While a number of strategies need to be pursued, the Reality Check report points out that when it comes to long term projected trends in the labour force, many organizations have identified the recruitment of younger workers as especially critical (Association of Municipal Administrators of Nova Scotia, 2006:12). However, it is clear that the incoming generation will be joining a very diverse workforce, where a number of different generations are working side by side. Kaye, Scheef and Thielfoldt (2003:25) note that organizations at the dawn of the $21^{\text {st }}$ century likely possess members of four generations working within them: the Silent Generation (born 1933-1945), Baby Boomers (born 1946-1964), Generation X (born 1965-1976), and maybe even some Millennials (born 1977-1998). These different generations are composed of individuals with their own unique personalities, identities, values and beliefs.

The Reality Check report describes in broad terms, the shared life experiences of each generation and how recruitment strategies should take the different generational values into account. Tying different generational values to recruitment strategies is becoming a well traveled path. In order to successfully recruit personnel in a competitive environment, it is argued, one must understand what motivates members of the different generational groups. There are traditional motivational factors such as compensation, benefits, job security and promotions, but there are other factors that speak to the workplace values of the newer generations. Chief among those values is workplace empowerment. 
Thus in keeping with the literature on recruitment, succession planning and intergenerational change, the Reality Check report argues that:

\begin{abstract}
.... recruiting the next generation of local government officials is one piece of a much larger picture - it must be seen within a broader workforce planning context that is linked to the organization's goals and objectives. Workforce planning involves an inter-related cycle of human resources activities including succession planning, recruitment/selection, training and development, performance management, rewards and recognition, career advancement and retention (Association of Municipal Administrators of Nova Scotia, 2006:17).
\end{abstract}

Since many of Nova Scotia's municipalities lack the resources for such sustained human resource planning and execution, the ability to change organizational cultures in favour of New Professionalism in order to attract the 'top talent' must come from province-wide support structures (Association of Municipal Administrators of Nova Scotia, 2006:21). The UNSM, AMA and the SNSMR are all tagged as necessary partners to develop the kind of leadership that is required to plan for and secure the necessary resources to attract the next generation of leaders (Association of Municipal Administrators of Nova Scotia, 2006:21). Recruitment strategies for attracting New Professionals were identified through Next Generation project focus groups, an employee survey and 'best practices' research (Association of Municipal Administrators of Nova Scotia, 2006:19). These are summarized in Figure 3.

Each of the strategies speaks to the need for municipal government transformation into 'post-bureaucratic' workplaces, which can tap into the skills sets, values and expectations of a new generation of managers. The pressures to do are increasing. As noted in a current public sector publication:

The renewal of the public service has been a focus for many public sector organizations across Canada in the past few years. An aging population, a competitive labour market and other challenges have turned succession planning into common practice within the public service. The face of the public service has begun a transformative change (Institute of Public Administration of Canada , 2009:18). 
Figure 3. Recruitment strategies for attracting new professionals were identified through "Next Generation" project focus groups, an employee survey and 'best practices' research. (Association of Municipal Administrators of Nova Scotia, 2006:19).

\section{RECRUITING THE NEXT GENERATION OF LOCAL GOVERNMENT OFFICIALS}

\section{DRIVERS}

\section{Leadership Support}

Awareness of Municipal Government as a Career Option

\section{Availability of Entry-Level Opportunities}

\section{Strategic Promotion and Advertising}

\section{Supportive Work Culture}

\section{Competitive Salaries and Benefits}

\section{Partnerships}

\section{Learning and Development} Opportunities

\section{SUPPORTING STRATEGIES}

- Implement annual CAO workforce information survey

- Provide online human resources information

- Provide networking opportunities for young talent

- Recognize workforce planning accountabilities for CAOs/Senior Managers

- Encourage municipal councils to promote municipal government as a career option

- Increase attendance at career fairs

- Offer job shadowing for school-age students

- Introduce career-day seminars for summer co-op students

- Reintroduce Municipal Awareness Week

- Improve the Municipal Internship Program

- Increase the use of co-op placements

- Develop a bridging program for co-op students

- Develop a municipal government career "brand"

- Subscribe to frequently used job search websites

- Enhance existing career opportunities websites

- Identify unconventional locations/methods for advertising

- Engage young talent in recruiting young talent

- Raise awareness of generational differences in the workplace

- Engage unions in workforce planning and recruitment strategies

- Encourage experienced employees to act as mentors/coaches to recruits

- Explore options for flexible work arrangements

- Clarify roles and responsibilities between councils and staff

- Review salaries and benefits packages

- Explore options for flexible, portable benefits

- Facilitate opportunities for informal working group sessions in various regions of the province

- Partner with universities and colleges to ensure programs are responsive to municipal needs

- Encourage partnering on the Municipal Internship Program

- Develop orientation kits for new employees

- Support young employees to form networks

- Encourage the development of annual learning plans for all employees

- Explore the potential of a leadership development program for municipal government 
And what would such a transformational workplace look like, courtesy of intergenerational change and the influence of Generation X and the Millennials? Kaye, Scheef and Thielfoldt (2003: 27-30) have asserted that transformed organizations will be marked by certain key dynamics. Workplaces will be more informal with employees given far more flexibility and independence in how they do their jobs. Flextime and telecommuting will be encouraged. Policies and programs promoting work-life balance will be expected. Good salaries will co-exist with good and interesting work. Young employees will expect strong and good mentors and teamwork will become the new working norm. Excessive hierarchy and a rules-bound corporate culture will be scorned in favour of flatter organizational structures promoting much greater informal and horizontal forms of communication and staff interaction. Participatory management will be promoted and expected, and employees will desire meaningful work, with project teams composed of a wide variety of employees and managers with diverse backgrounds and years of service within the organization. Employee involvement, creativity and risktaking will be supported by management as managers and new employees, new professionals, seek to find newer, better, more innovative and more economical, efficient and effective ways and means of achieving organizational ends. And the New Professionals will be expecting to have work that is intellectually challenging, interesting and engaging, and fun. New Professionals, as such, are expected to bring with them the New Professionalism.

The promise of New Professionalism as an important element in transforming municipal government is considerable. And despite the competitive labour market, municipal management careers can hold some attraction for young talent. Because many of the municipalities in Nova Scotia do not have a dedicated human resource function for example, a new manager has to be more of a generalist than a specialist. And because a new manager is likely to be involved in a number of areas, there is substantial learning and development that will take place on the job. As indicated above, New Professionals consistently rate training and development as an important aspect of their career planning. As well, municipalities possess flatter organizational structures than more senior levels of government, which offer the possibility of promoting greater informal and horizontal forms of communication and staff interaction. New Professionals also crave access to decision-makers and that level of interaction creates the opportunity for the kind of meaningful work that leads to the development of public policy. And in helping to develop that policy, New Professionals can work at the 'grass roots' level with 
various community-based groups. Other municipal career recruitment advantages identified in the Reality Check report include the following (Association of Municipal Administrators of Nova Scotia, 2006:42):

- Large employer within a small town environment

- Good benefits and pension package

- Stability of employer, policies and structure

- Exciting opportunities for specific fields such as environmental management

- Possibility for movement between municipalities

- Competitive salaries (for some municipalities)

- Good business hours (for some municipalities)

- Work-life balance policies (for some municipalities).

As noted in the first bullet point, there can be a 'quality of life' geographical advantage to living and working in a smaller community. Work-life balance issues may also be easier to address away from the logistical challenges of living in a large urban centre. Good benefits and pension packages are a recruitment attraction for any generation. A management career in municipal government can also allow for the direct application of one's field of study. In our discussions with federal public service new professionals, we found an interest in 'lateral' moves from one branch of a department to another in order to learn and develop (Johnson and Molloy, 2010) Lateral moves between municipalities may hold similar promise in recruiting a new generation of managers.

The last three bullet points are qualified, in recognition of some of the many recruitment challenges which smaller municipalities face in a competitive labour environment. Many municipalities in Nova Scotia are struggling financially. This lack of resources underscores the need for partnerships through the AMA, UNSM and SNSMR, in order to identify, prioritize and engage in longer term planning on issues such as succession planning. Also, in addition to the financial constraints that limit what many municipalities can offer New Professional managers, working in a municipal environment is considerably different from what one finds in the larger senior government public services. Some municipal managers describe the experience as 'working in a fish bowl', where politics and administration mingle in rather undefined way. Next Generation project focus group respondents pointed out that technically the role of the elected council is to set policy and the role of the administrators is to implement those policies. However, in many cases the boundaries between these two 
areas of responsibility are very blurred. This creates challenges for administrators in fulfilling their roles effectively (Association of Municipal Administrators of Nova Scotia, 2006:42). Such a 'traditional' municipal organizational culture can be 'light years' away from the transformative, New Professional workplace that incoming generations seek. According to Next Generation project focus group respondents: "some municipalities have trouble retaining people due to their very reactive, political environment which can cause new employees to feel their professional integrity and ethics are being compromised” (Association of Municipal Administrators of Nova Scotia, 2006:44).

Similar negative perceptions have led senior levels of government to undertake 'rebranding' exercises in order to promote the federal and provincial public services as employers of choice. This re-branding is proving to be successful. Nova Scotia municipal governments are being urged to develop strategies in order to educate the public "to understand the political and economic environment that municipalities must operate within” (Association of Municipal Administrators of Nova Scotia, 2006:41). Possible strategies include working with educational institutions at all levels to raise people's understanding of what municipalities do and how they do it, and bringing back a 'municipal awareness' week (Association of Municipal Administrators of Nova Scotia, 2006:41). It is hoped that such strategies will help to promote municipalities as a career for a New Professional and also perhaps assist in creating interest in the kind of municipal organizational change that a new generation of municipal leaders can bring about.

\section{Conclusion}

Recruiting the next generation of municipal managers in Nova Scotia is an ongoing challenge. In order to meet that challenge, municipalities are working in partnership with the AMA, UNSM and SNSMR to engage in longer term human resource planning. The Next Generation project is one outcome of such planning and its report recommendations are in line with both what senior levels of government have been doing, and what the organizational and, intergenerational change literature recommends. Implementing such change is very difficult, however, due to the financial and organizational pressures facing many Nova Scotia municipalities. To this point, progress has been modest. The slow pace of change also raises intriguing questions regarding institutional capacity and leadership at the local level. Nova Scotia municipalities are knowledgeable of the demographic challenges they face, as well as the threats and opportunities involved. 
Some leaders within these organizations are meeting the call for effective policy and program responses to these threats and opportunities. But these leadership initiatives confront local government environments all too often characterized by chronic underfunding, parochialism, anti-government bias, institutional inertia, and political attitudes based upon short-term electoral calculations. The ability of municipal governments within Nova Scotia to effectively bring about essential workforce and workplace change, to embrace the potential for New Professionalism and to recruit the New Professionals they so urgently need, remains an open and complicated question. The institutional spirit may be willing but organizational and leadership capacity may be found wanting.

\section{References:}

Association of Municipal Administrators of Nova Scotia (Prepared by Charlton, P. and MathesonCoutu, A.) 2006, 'Reality Check: Do You Know Where Your People Are? Attracting the Next Generation of Municipal Government Managers in Nova Scotia', Halifax, Nova Scotia.

Aucoin, P. 1995, The New Public Management: Canada in Comparative Perspective, Ottawa: Institute for Research on Public Policy.

Borins, S. F. 1995, 'Public Sector Innovation: The Implications of New Forms of Organization and Work', in B. G. Peters and D. J. Savoie (eds), Governance in a Changing Environment, Montreal and Kingston: Canadian Centre for Management Development.

Brown, J. and Williams, L. 2003, 'The $21^{\text {st }}$ Century Workforce: Implications for HR', in M. Effron, R. Gandossy and M. Goldsmith (eds), Human Resources in the $21^{\text {st }}$ Century. Hoboken, New Jersey: John Wiley \& Sons.

CBC News 2005, 'Boomers retire idea of Freedom 55, StatsCan analyst suggests', Toronto: CBC News. Viewed 24 January, $2007<\underline{<t t p / / w w w . c b c . c a / n e w s / s t o r y / 2007 / 01 / 24 / b o o m e r s-~}$ work.html>

Centre for Leadership and Learning, Ministry of Government Services 2006, Ontario Public Service Talent Management, A Guide, Ontario Public Service.

Dychtwald, K., T. J. Erickson and R. Morison 2006, Workforce Crisis: How to Beat the Coming Shortage of Skills and Talent, Boston: Harvard Business School Press.

Gavett, L. and Throckmorton, R. 2007, Bridging the Generation Gap: How to Get Radio Babies, Boomers, Gen Xers and Gen Yers to Work Together and Achieve More, Franklin Lakes, New Jersey: Career Press.

Government of Canada 2006, Population Aging and Life-Course Flexibility Briefing NotePolicy Research Initiative, Ottawa.

Johnson, D. and Molloy, A. 2010, The New Professionals: Intergenerational Change and Public Sector Renewal in Ottawa, Manuscript under review, Institute of Public Administration of Canada.

Kaye, B., Scheef, D. and Thielfoldt, D. 2003, 'Engaging the Generations', in M. Effron, R. Gandossy and M. Goldsmith (eds.), Human Resources in the $21^{\text {st }}$ Century, Hoboken, New Jersey: John Wiley \& Sons.

Kernaghan, K., Marson, B. and Borins, S. 2000, The New Public Organization, Toronto: The Institute of Public Administration of Canada - No.24. 
Lancaster, L. C. and Stillman, D. 2005, When Generations Collide: Who They Are, Why They Clash, How to Solve the Generational Puzzle at Work, New York: Collins Business.

Manitoba Civil Service Commission 2008, 'New Professionals Network - Government of Manitoba’. Accessed 14 January, $2008<$ http//:www.gov.mb.ca/csc/npn/background.html $>$.

Martin, C. A. and Tulgan, B. 2006, Managing the Generation Mix: From Urgency to Opportunity, Amherst: Massachusetts: HRD Press.

New Professionals Organizing Committee 2001, New Professionals Driving a New Public Service: A Report, Toronto: New Professionals Organizing Committee.

Osborne, D. and Gaebler, T. 1993, Reinventing Government: How the Entrepreneurial Spirit is Transforming the Public Sector, New York: Plume Books.

Public Service Commission, Government of Saskatchewan 2008, 'About the New Professionals Network', Government of Sakatchewan. Accessed 11 January, 2008 $<$ http://www.psc.gov.sk.ca/Default.aspx?DN=270055d69-22b3-4457-803c-50cec6b9d26>

Purchase, B. and Hirshorn, R. 1994, Searching for Good Governance, Kingston: School of Policy Studies, Queen's University.

Ramlo, A. and Berlin, R. 2006, A Perfect Storm: Sustaining Canada's Economy During Our Next Demographic Transformation, The Urban Futures Institute Report - No.66, Vancouver.

Savoie, D. J. 1995, 'What is wrong with the New Public Management', Canadian Public Administration, vol. 38, pp. 112-21.

Sherwood, D. and Matthews, L. 2003, New Leaders, New Professionals, UBC Government Relations - No. 10, Vancouver.

Task Force on Public Service Values and Ethics 1996, A Strong Foundation, Ottawa: Canadian Centre for Management and Development.

The Institute of Public Administration of Canada 2003, New Professionals' Program, Toronto: Institute of Public Administration of Canada.

The Institute of Public Administration of Canada 2009, New Professionals Communities: Supporting the renewal of the public service, Public Sector Management, Toronto: The Institute of Public Administration of Canada.

Thomas, P. G. 1993, 'Coping with Change: How Public and Private Organizations Read and Respond to Turbulent Environments', in F. L. Seidle (ed.), Rethinking Government: Reform or Reinvention?, Montreal: Institute for Research on Public Policy.

Trebilcock, M. J. 1994, The Prospects for Reinventing Government, Toronto: C.D. Howe Institute.

Union of Nova Scotia Municipalities 2007, 'Reality Check: Do You Know Where Your People Are? Attracting the Next Generation of Municipal Government Managers in Nova Scotia', Union of Nova Scotia Municipalities, Spring Workshop.

Youth and New Professionals, Centre for Leadership and Learning 2006, Youth and New Professionals, Investing in Tomorrow's Workforce Today, Ontario: The Ontario Public Service, Ministry of Government Services.

Zemke, R., Raines, C. and Filipczak, B. 2000, Generations at Work: Managing the Clash of Veterans, Boomers, Xers, and Nexters in Your Workplace, New York: AMACOM. 